\title{
Antibacterial activity of biogenic silver nanoparticles synthesized with gum ghatti and gum olibanum: a comparative study
}

\begin{abstract}
Aruna Jyothi Kora ${ }^{1}$ and Rao Beedu Sashidhar ${ }^{2}$
Presently, silver nanoparticles produced by biological methods have received considerable significance owing to the natural abundance of renewable, cost-effective and biodegradable materials, thus implementing the green chemistry principles. Compared with the nanoparticles synthesized using chemical methods, most biogenic silver nanoparticles are protein capped, which imparts stability and biocompatibility, and enhanced antibacterial activity. In this study, we compared the antibacterial effect of two biogenic silver nanoparticles produced with natural plant gums: gum ghatti and gum olibanum against Gramnegative and Gram-positive bacteria. Bacterial interaction with nanoparticles was probed both in planktonic and biofilm modes of growth; employing solid agar and liquid broth assays for inhibition zone, antibiofilm activity, inhibition of growth kinetics, leakage of intracellular contents, membrane permeabilization and reactive oxygen species production. In addition, cytotoxicity of the biogenic nanoparticles was evaluated in HeLa cells, a human carcinoma cell line. Antibacterial activity and cytotoxicity of the silver nanoparticles synthesized with gum ghatti (Ag NP-GT) was greater than that produced with gum olibanum (Ag NPOB). This could be attributed to the smaller size $(5.7 \mathrm{~nm})$, monodispersity and zeta potential of the Ag NP-GT. The study suggests that Ag NP-GT can be employed as a cytotoxic bactericidal agent, whereas Ag NP-OB $(7.5 \mathrm{~nm})$ as a biocompatible bactericidal agent.
\end{abstract}

The Journal of Antibiotics (2015) 68, 88-97; doi:10.1038/ja.2014.114; published online 20 August 2014

\section{INTRODUCTION}

Most of the chemical methods used for metallic nanoparticle synthesis require toxic organic solvents and reactive reducing agents, which pose environmental and biological risks. ${ }^{1,2}$ Conversely, physical methods necessitate sophisticated equipment, stringent conditions, are limited to low production rates, high energy consumption and consequently high cost. ${ }^{3}$ Thus, the thrust has shifted toward green chemistry-based synthesis of nanoparticles using biologicals, as a simple and viable alternative. Furthermore, there is natural abundance of renewable, cost-effective and biodegradable materials from diverse sources including bacteria, ${ }^{4}$ fungi, ${ }^{5}$ algae ${ }^{6}$ and plants. ${ }^{7}$ Most of the chemogenic silver nanoparticles are cytotoxic and nonbiocompatible due to contamination from chemical precursors, residual solvent toxicity and generation of hazardous by-products and so on. ${ }^{8}$ Hence, they are not ideal candidates for biomedical or pharmaceutical applications. In this context, we have explored and developed facile and green routes for the synthesis of silver nanoparticles from silver nitrate using nontoxic, renewable natural plant polymers of Indian origin: gum ghatti (Anogeissus latifolia) ${ }^{9}$ and gum olibanum (Boswellia serrata). ${ }^{10}$

Toxicity of silver nanoparticles synthesized by various reductants and methodologies has been demonstrated to a number of bacteria including Escherichia coli, Pseudomonas aeruginosa, Staphylococcus aureus, methicillin-resistant S. aureus, S. epidermidis, Streptococcus faecalis, Bacillus subtilis, Mycobacterium smegmatis, M. bovis, Vibrio cholera, Salmonella typhus, Enterococcus faecalis, E. faecium, Klebsiella pneumonia, Syphilis typhus and Acinetobacter baumanii. ${ }^{11-15}$ A recent comparative study of biogenic and protein-capped silver nanoparticles and chemically synthesized silver nanoparticles found that, biogenic nanoparticles were more bactericidal than chemically synthesized nanoparticles. ${ }^{16}$ The present study compares the antibacterial activity of two biogenic, protein-capped silver nanoparticles synthesized from two natural plant gums against Gram-negative and Gram-positive planktonic and biofilm bacteria. The integrated methodologies used include well diffusion, microbroth dilution, antibiofilm activity, bacterial growth kinetics, leakage of cytoplasmic contents and membrane permeabilization assay, and impact of reactive oxygen species (ROS) on antibacterial activity.

\section{MATERIALS AND METHODS}

Bacterial strains and silver nanoparticles

Gram-negative (E. coli ATCC 25922, E. coli ATCC 35218, P. aeruginosa ATCC 27853) and Gram-positive (S. aureus ATCC 25923) bacteria were used as model test strains. The methods for silver nanoparticle preparation using gum

${ }^{1}$ National Centre for Compositional Characterisation of Materials (NCCCM), Bhabha Atomic Research Centre, Hyderabad, India and ${ }^{2}$ Department of Biochemistry, University College of Science, Osmania University, Hyderabad, India

Correspondence: Professor RB Sashidhar, Department of Biochemistry, University College of Science, Osmania University, Hyderabad, Andhra Pradesh 500 007, India. E-mail: sashi_rao@yahoo.com

Received 7 May 2014; revised 30 June 2014; accepted 13 July 2014; published online 20 August 2014 
ghatti and gum olibanum were standardized using methods previously reported. ${ }^{9,10}$ In brief, gum ghatti silver nanoparticles (Ag NP-GT) with a mean particle size of $5.7 \pm 0.2 \mathrm{~nm}$ were synthesized by autoclaving $0.1 \%$ gum ghatti solution containing $1 \mathrm{~mm}$ silver nitrate at $121^{\circ} \mathrm{C}, 15 \mathrm{psi}$ for $30 \mathrm{~min}$. Gum olibanum silver nanoparticles (Ag NP-OB) with a mean particle size of $7.5 \pm 3.8 \mathrm{~nm}$ were prepared by autoclaving $0.5 \%$ gum olibanum extract containing $1 \mathrm{~mm}$ silver nitrate at $121^{\circ} \mathrm{C}, 15 \mathrm{psi}$ for $30 \mathrm{~min}$ (Supplementary Figure 1). The inductively coupled plasma-optical emission spectrometer (ICPOES) technique was employed to determine the total silver content in the synthesized nanoparticles. The samples were digested with ultra-pure nitric acid and the digested samples were analyzed using a Jobin Yvon Horiba JY2000 ICP-OES (Longjumeau, France) equipped with a Meinhard concentric nebulizer and a cyclonic spray chamber. The zeta potential of the nanoparticle solutions was measured with a Malvern Zetasizer Nanosystem (Malvern, UK). The absorbance and fluorescence measurements were carried out with Biotek Synergy H1 plate reader (Winooski, VT, USA).

\section{Antibacterial assays}

Well diffusion assay. The bacterial suspension was prepared by growing a single colony overnight in nutrient broth and adjusting the turbidity to 0.5 McFarland standard. Mueller Hinton agar (MHA) plates were inoculated with this bacterial suspension and $5 \mu \mathrm{g}$ of silver nanoparticles were added to the center well with a diameter of $6 \mathrm{~mm}$. The negative control plates were maintained with autoclaved gum-loaded wells. Erythromycin (15 $\mu \mathrm{g}$ per disk) (HiMedia Chemicals Pvt. Ltd, Mumbai, India)-loaded culture plates were included as positive control. Plates were incubated at $37^{\circ} \mathrm{C}$ for $24 \mathrm{~h}$ in a bacteriological incubator and the zone of inhibition (ZOI) was calculated as $\mathrm{ZOI}=$ diameter of total inhibition - diameter of the well.

Micro-broth dilution method. The micro-broth dilution method ${ }^{17}$ was used to determine the MIC and MBC of silver nanoparticles against test bacterial strains. Sterile polystyrene microtiter plate wells were inoculated with $200 \mu \mathrm{l}$ of nutrient broth containing $10^{6} \mathrm{CFU} \mathrm{ml}^{-1}$ and loaded with different concentrations of nanoparticles $\left(1-15 \mu \mathrm{g} \mathrm{ml}^{-1}\right)$. Plates were incubated in static mode at $37^{\circ} \mathrm{C}$ for $48 \mathrm{~h}$. Control wells were maintained with medium containing bacterial suspension. Bacterial growth was measured by visual inspection for turbidity, and absorbance at $600 \mathrm{~nm}$. The concentration at which there was no increase in absorbance was taken as the MIC. A volume of $100 \mu \mathrm{l}$ of bacterial suspension from each negative well (no visual turbidity) was plated on nutrient agar. The lowest concentration at which no colonies formed on nutrient agar plates was taken as the MBC.

In vitro biofilm formation assay. The effect of silver nanoparticles on biofilm formation was assessed by a modified microtiter plate assay. ${ }^{18}$ Sterile polystyrene microtiter plate wells were inoculated with $200 \mu \mathrm{l}$ of nutrient broth containing $10^{6} \mathrm{CFU} \mathrm{ml}^{-1}$ and loaded with $2 \mu \mathrm{g} \mathrm{ml}^{-1}$ of silver nanoparticles. The plates were incubated in static mode at $37^{\circ} \mathrm{C}$ for $48 \mathrm{~h}$. The negative and positive control wells were maintained without silver nanoparticles and ciprofloxacin-treated bacterial suspensions, respectively. After $48 \mathrm{~h}$ of growth, the medium in the wells was removed and washed with sterile PBS to remove loosely attached bacteria. Wells were then stained with $200 \mu \mathrm{l}$ of $0.1 \%$ crystal violet and incubated for $30 \mathrm{~min}$, washed and air dried. Bound stain was solubilized in $200 \mu \mathrm{l}$ of $95 \%$ ethanol, and absorbance measured at $590 \mathrm{~nm}$.

Bacterial growth curve. The bacterial growth curve was monitored by inoculating the microtiter plate wells with nutrient broth containing $10^{6}$ $\mathrm{CFU} \mathrm{ml}^{-1}$ and loaded with various concentrations of nanoparticles $\left(1-10 \mu \mathrm{g} \mathrm{ml}^{-1}\right)$. The plates were incubated at $37^{\circ} \mathrm{C}, 100$ r.p.m. and the absorbance was recorded at $600 \mathrm{~nm}$ for $48 \mathrm{~h}$ using Biotek Synergy H1 plate reader. ${ }^{15}$

Leakage of cytoplasmic contents. The effect of silver nanoparticles on membrane damage was studied by quantifying leaked cytoplasmic nucleic acids and proteins. ${ }^{19-21}$ The bacterial cell suspension with an absorbance 0.5 at $600 \mathrm{~nm}$ was prepared in sterile saline and treated with $5 \mu \mathrm{g} \mathrm{ml}^{-1}$ of silver nanoparticles for $1 \mathrm{~h}$. The negative and positive controls were maintained without silver nanoparticles and by boiling the suspensions at $100^{\circ} \mathrm{C}$ for $30 \mathrm{~min}$. Samples were centrifuged at 10000 r.p.m. for $10 \mathrm{~min}$ and supernatants were measured for absorbance at 260 and $280 \mathrm{~nm}$.

Outer membrane damage. The outer membrane damage in Gram-negative bacteria induced by silver nanoparticles was monitored using a fluorescent probe, $N$-phenyl naphthylamine (NPN) permeabilization assay. ${ }^{20,22}$ A stock solution of $5 \mathrm{~mm}$ NPN in acetone was diluted with $5 \mathrm{~mm}$ HEPES buffer, $\mathrm{pH} 7.2$ to make a $0.2 \mathrm{~mm}$ NPN working solution. Gram-negative P. aeruginosa 27853, E. coli 25922 and E. coli 35218 were used in the assay. Bacterial cultures in nutrient broth were grown overnight, harvested, washed and resuspended in 5 mM HEPES buffer, pH 7.2 and the suspension was adjusted to obtain an absorbance 0.5 at $600 \mathrm{~nm}$. Silver nanoparticles $\left(3 \mu \mathrm{g} \mathrm{ml}^{-1}\right)$ were added to $10 \mu \mathrm{l}$ of $0.2 \mathrm{~mm}$ NPN solution in black microtiter plates. A volume of $200 \mu \mathrm{l}$ bacterial suspension was added to the above mixture and incubated at $37^{\circ} \mathrm{C}$ for $10 \mathrm{~min}$. Bacterial suspensions without silver nanoparticles and with $30 \mu \mathrm{M} \mathrm{H}_{2} \mathrm{O}_{2}$ served as negative and positive controls, respectively. Fluorescence at $420 \mathrm{~nm}$ with an excitation wavelength of $350 \mathrm{~nm}$ was recorded.

Effect of antioxidant on bactericidal activity of silver nanoparticles. To assess the impact of free radicals on the bactericidal activity of silver nanoparticles, MHA plates were supplemented with silver nanoparticles at $5 \mu \mathrm{g} \mathrm{ml}^{-1}$. The antioxidant $N$-acetylcysteine (NAC) was added to these plates at $10 \mathrm{~mm}$ concentration. These plates were inoculated with known CFU of bacteria by spread plating and the number of surviving bacteria was counted after $24 \mathrm{~h}$ of incubation at $37^{\circ} \mathrm{C}$. The nanosilver-free control plates were maintained with NAC. ${ }^{12}$

Detection of intracellular ROS. The generation of intracellular ROS generation in nanoparticle-treated bacterial cells was determined using dichlorodihydrofluorescein diacetate $\left(\mathrm{H}_{2} \mathrm{DCFDA}\right)$, an intracellular ROS indicator. A stock solution of $2 \mathrm{mM} \mathrm{H}_{2}$ DCFDA was prepared in dimethyl sulfoxide and stored under dark at $-40^{\circ} \mathrm{C}$. The overnight grown bacterial cultures in nutrient broth were harvested, washed and resuspended in $0.1 \mathrm{M}$ sodium phosphate buffer, $\mathrm{pH} 7.2$ and the cell suspension was adjusted to obtain an $\mathrm{A}_{600 \mathrm{~nm}}$ of 0.5. To $20 \mathrm{ml}$ of the bacterial suspension, $100 \mu \mathrm{l}$ of $2 \mathrm{mM} \mathrm{H}_{2}$ DFDA stock solution was added to get a final concentration of $10 \mu \mathrm{m}$ and incubated under dark at $37^{\circ} \mathrm{C}$ for $60 \mathrm{~min}$. After washing, the cells were suspended in the same buffer and the $200 \mu \mathrm{l}$ of $\mathrm{H}_{2}$ DFDA-treated, washed bacterial cell suspensions were aliquoted in a 96 -well black plate and $2 \mu \mathrm{g} \mathrm{ml}^{-1}$ of silver nanoparticles were added and incubated under dark at $37^{\circ} \mathrm{C}$. The negative and positive controls were maintained with nanosilver-free and $30 \mu \mathrm{M} \quad \mathrm{H}_{2} \mathrm{O}_{2}$-treated bacterial suspensions, respectively. After $60 \mathrm{~min}$ of incubation, the fluorescence intensity was recorded at an excitation wavelength of $490 \mathrm{~nm}$ and an emission wavelength of $520 \mathrm{~nm}^{11}$

MTT assay. For evaluating the cytotoxicity of the prepared nanoparticles on mammalian cells, the 3-(4, 5 dimethyl-2-yl)-2, 5-diphenyltetrazolium bromide (MTT) assay ${ }^{23}$ was carried out with human cervical cancer cell line HeLa. The 96-well microtiter plates were seeded with $10^{5}$ cells per well in Dulbecco's modified Eagle's medium containing 10\% serum at 5\% $\mathrm{CO}_{2}$ concentration and exposed to silver nanoparticles at different concentrations $(1,2.5,5,10,25$ and $50 \mu \mathrm{g} \mathrm{ml}^{-1}$ ) and incubated for $24-72 \mathrm{~h}$ at $37^{\circ} \mathrm{C}$ in a INC 108 Memmert $\mathrm{CO}_{2}$ incubator (Memmert,Schwabach, Germany). The negative and positive controls were maintained with nanosilver-free and doxorubicin $\left(13 \mu \mathrm{g} \mathrm{ml}^{-1}\right)$ treated cells, respectively. After the completion of exposure, the medium was removed from each well and was replaced with $200 \mu$ l of fresh medium containing $10 \mu \mathrm{l}$ of MTT $\left(5 \mathrm{mg} \mathrm{ml}^{-1}\right)$ and incubated for $4 \mathrm{~h}$ at $37^{\circ} \mathrm{C}$. The medium was decanted and the resulting formazan crystals were dissolved in $200 \mu \mathrm{l}$ of dimethyl sulfoxide per well. The absorbance was measured at $540 \mathrm{~nm}$ using Biotek Synergy H1 plate reader and the \% viability was calculated by considering untreated controls as $100 \%$ viable.

\section{RESULTS AND DISCUSSION}

\section{Zone of inhibition}

The well diffusion method was used to study the antibacterial activity of the synthesized silver nanoparticles. After $24 \mathrm{~h}$ of incubation at $37^{\circ} \mathrm{C}$, growth suppression was observed in plates loaded with $5 \mu \mathrm{g}$ of 
silver nanoparticles and negative control plates loaded with either of the autoclaved gum did not produce any ZOI. As expected, the positive control plates loaded with erythromycin antibiotic exhibited considerable inhibition zones. The ZOI observed with both the silver nanoparticles against various bacterial strains are shown in Table 1. The ZOI recorded with all test strains was in the order of Ag NPGT $>$ Ag NP-OB. It was earlier reported that the antibacterial activity of the nanoparticles is directly proportional to the zeta potential. ${ }^{24}$ The measured zeta potential values for the Ag NP-GT and Ag NP-OB were $-22.4 \pm 8.7 \mathrm{mV}$ and $-14.9 \pm 6.6 \mathrm{mV}$, respectively.

In a strain-specific antibacterial study, ZOI of $14-15$ and $16 \mathrm{~mm}$ were reported for $S$. aureus and E. coli strains, respectively. These thiol-capped nanoparticles with an average size of $3.3 \mathrm{~nm}$ were produced by borohydride reduction and used at a nanosilver loading of $100 \mu \mathrm{g}$. Thus, the effective inhibition observed in our studies was found to be higher than the reported values for chemically produced silver nanoparticles. ${ }^{25}$ To further evaluate the results, we have compared our data with the available reports on biogenic silver nanoparticles. With the same strains, ZOI of 9 and $8 \mathrm{~mm}$ were noted at $20 \mu \mathrm{g}$ loading. Here, the silver nanoparticles of 3-30 nm size were biosynthesized by the fungus Aspergillus niger. ${ }^{26}$ Thus, the ZOI values observed by us with silver nanoparticles synthesized by gums at $5 \mu \mathrm{g}$ loading were higher than the reported values. On the basis of these results, it can be concluded that both the biogenic nanoparticles had significant antibacterial action on both the Gram classes of bacteria. In addition to particle size, the surface-capping agent has an import role in determining the bactericidal activity of silver nanoparticles. ${ }^{16,27}$ Hence, the biogenic antibacterial silver nanoparticles generated with gums have advantage over other chemically produced (chemogenic) nanoparticles.

\section{Determination of MIC and MBC}

The growth inhibition effect of silver nanoparticles against bacterial strains was measured by MIC. For S. aureus 25923, P. aeruginosa 27853, E. coli 25922 and E. coli 35218, the MIC values of both the silver nanoparticles were $10.0,5.0,2.0$ and $2.0 \mu \mathrm{g} \mathrm{ml}^{-1}$, respectively. In a previous antibacterial study, MIC values of 8-32, 16 and $32 \mu \mathrm{g} \mathrm{ml}^{-1}$ were reported for $S$. aureus, P. aeruginosa and E. coli strains, respectively. These nanoparticles of $13 \mathrm{~nm}$ size were prepared using culture supernatant of $P$. aeruginosa. ${ }^{4}$ For the respective $S$. aureus, $P$. aeruginosa and $E$. coli strains, the MIC values were observed to be lower by 3.2-, 3.2- and 16-fold, respectively. Thus, the silver nanoparticles synthesized using plant gums were found to be more potent bactericidal agents in terms of concentration. The highest value of MIC was noted for S. aureus 25923 followed

Table 1 The inhibition zones $(\mathrm{mm})$ observed with different bacterial culture plates loaded with biogenic silver nanoparticles and erythromycin

\begin{tabular}{lcccc}
\hline & \multicolumn{4}{c}{ Zone of inhibition $(\mathrm{mm})^{\mathrm{a}}$} \\
\cline { 2 - 5 } Test compound & S. aureus & P. aeruginosa & E. coli & E. coli \\
$(\mu g)$ & 25923 & 27853 & 25922 & 35218 \\
\hline Ag NP-GT (5) & $12.2 \pm 0.2$ & 11.0 & 9.0 & $8.0 \pm 0.1$ \\
Ag NP-OB (5) & $10.7 \pm 0.2$ & 7.5 & $8.0 \pm 1.0$ & 5.5 \\
Erythromycin (15) & $23.5 \pm 1.0$ & $11.0 \pm 1.1$ & $7.0 \pm 1.1$ & $9.0 \pm 1.1$
\end{tabular}

Abbreviations: Ag NP-GT, silver nanoparticles synthesized with gum ghatti; Ag NP-OB, silver nanoparticles synthesized with gum olibanum.

avalues are mean \pm s.d. $(n=3)$ by $P$. aeruginosa 27853. The lowest value of MIC was observed for both the E. coli strains. From the results, it is evident that among the strains selected for testing, E. coli was more sensitive toward the bactericidal activity of silver nanoparticles used in this study. These findings on susceptibility of E. coli toward silver nanoparticles are in line with the earlier-reported studies. ${ }^{11,12}$

Most of the MBC values were same as MIC and with $P$. aeruginosa 27853 a MBC value of $12 \mu \mathrm{g} \mathrm{ml}^{-1}$ was noted for both the nanoparticles. Also, higher MBC values were observed for S. aureus 25923 $\left(12 \mu \mathrm{g} \mathrm{ml}^{-1}\right)$ and E. coli $35218\left(3 \mu \mathrm{g} \mathrm{ml}^{-1}\right)$ with Ag NP-OB. The MBC values detected for $S$. aureus and E. coli strains were lower by 4 and $33 \times$, respectively; when compared with PVP-stabilized nanoparticles of $10 \mathrm{~nm}$ size synthesized by ultrasonic irradiation. ${ }^{11}$

\section{Antibiofilm activity}

The inhibition of biofilm formation by silver nanoparticles was studied with static microtiter plate assay at a concentration of $2 \mu \mathrm{g} \mathrm{ml}^{-1}$ (Table 2). The Ag NP-GT was able to impede the biofilm formation by $92.9 \%, 81.1 \%, 78.7 \%$ and $64.5 \%$, respectively in $E$. coli 35218 , E. coli 25922, P. aeruginosa 27853 and S. aureus 25923. Against the same strains, inhibition was $92.9 \%, 82.9 \%, 77.0 \%$ and $61.4 \%$ with $\mathrm{Ag}$ NP-OB, respectively. In the case of positive control, the observed inhibition was $93.3 \%, 83.1 \%, 39.4 \%$ and $73.4 \%$ with the respective bacterial strains. Notably, the activity of both the biogenic nanoparticles against $P$. aeruginosa 27853 biofilm formation was nearly twofold as compared with the positive control ciprofloxacin. The employed silver particles exhibited more or less similar antibiofilm activity against the rest of the test strains. Among the selected strains, S. aureus 25923 and $P$. aeruginosa 27853 were least susceptible to the antibiofilm activity of nanoparticles owing to the production of exopolysaccharides, which are needed for bacterial adhesion to the surface during biofilm formation. ${ }^{28}$ These results indicate that the biogenic silver nanoparticles synthesized with plant gums demonstrate strong bactericidal activity as well as antibiofilm activity.

\section{Bacterial growth kinetics in the presence of nanosilver}

The growth inhibition of bacteria was investigated in nutrient broth supplemented with silver nanoparticles $\left(0-10 \mu \mathrm{g} \mathrm{ml}^{-1}\right)$ for $48 \mathrm{~h}$ at $600 \mathrm{~nm}$. The kinetics of the all the growth curves obey typical pattern; a lag phase, an exponential phase and a stationary phase. For E. coli 25922, the lag phase was reduced to $3 \mathrm{~h}$ for the concentrations up to $5 \mu \mathrm{g} \mathrm{ml}^{-1}$ of Ag NP-GT. Even the highest tested concentrations of $10 \mu \mathrm{g} \mathrm{ml}^{-1}$ limited the lag phase to $4 \mathrm{~h}$ and did not cause complete growth inhibition (Figure 1a). In the case of Ag NP-OB, the concentrations beyond $4 \mu \mathrm{g} \mathrm{ml}^{-1}$ induced a lag phase for $8 \mathrm{~h}$ and

Table 2 The percentage inhibition in biofilm formation by different bacterial strains treated with biogenic silver nanoparticles and ciprofloxacin

\begin{tabular}{lcccc}
\hline & \multicolumn{4}{c}{ Biofilm inhibition (\%) } \\
\cline { 2 - 5 } Test compound & S. aureus & P. aeruginosa & E. coli & E. coli \\
$\left(\mu g \mathrm{~m}^{-1}\right)$ & 25923 & 27853 & 25922 & 35218 \\
\hline Ag NP-GT (2) & $64.5 \pm 3.5$ & $78.7 \pm 0.8$ & $81.1 \pm 1.5$ & $92.9 \pm 0.4$ \\
Ag NP-OB (2) & 61.4 & $77.0 \pm 1.6$ & $82.9 \pm 0.4$ & $92.9 \pm 0.4$ \\
Ciprofloxacin (0.1) & 73.0 & $39.4 \pm 3.5$ & 83.1 & $93.3 \pm 0.6$ \\
\hline $\begin{array}{l}\text { Abbreviations: Ag NP-GT, silver nanoparticles synthesized with gum ghatti; Ag NP-OB, silver } \\
\text { nanoparticles synthesized with gum olibanum. } \\
\text { aValues are mean } \pm \text { s.d. }(n=3) .\end{array}$
\end{tabular}


a

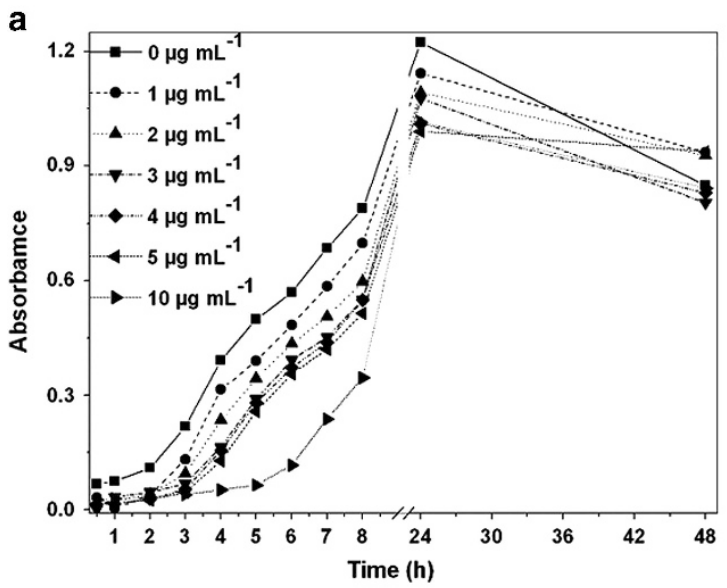

c

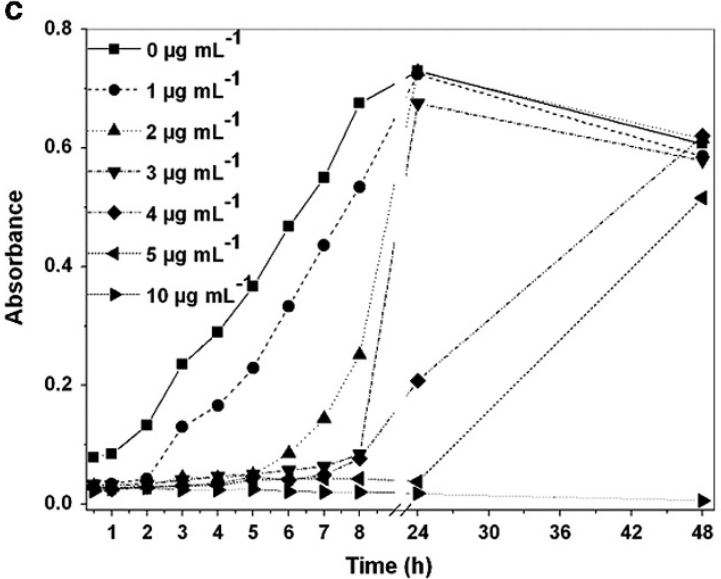

b

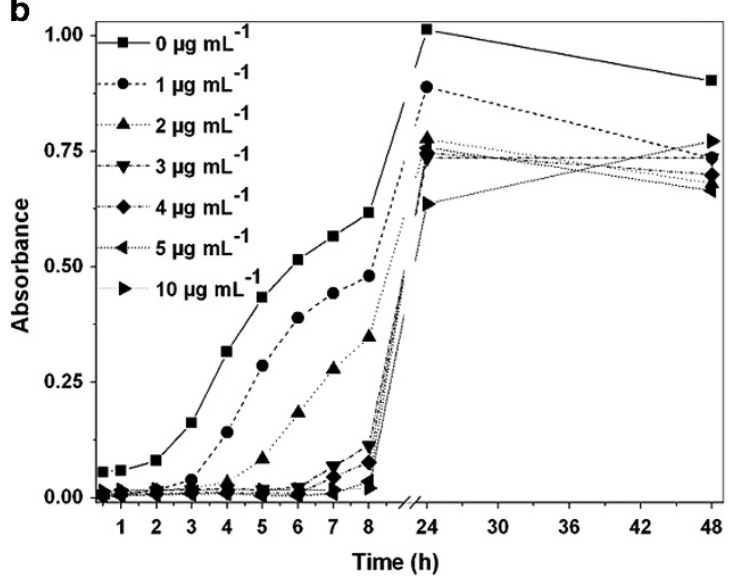

d

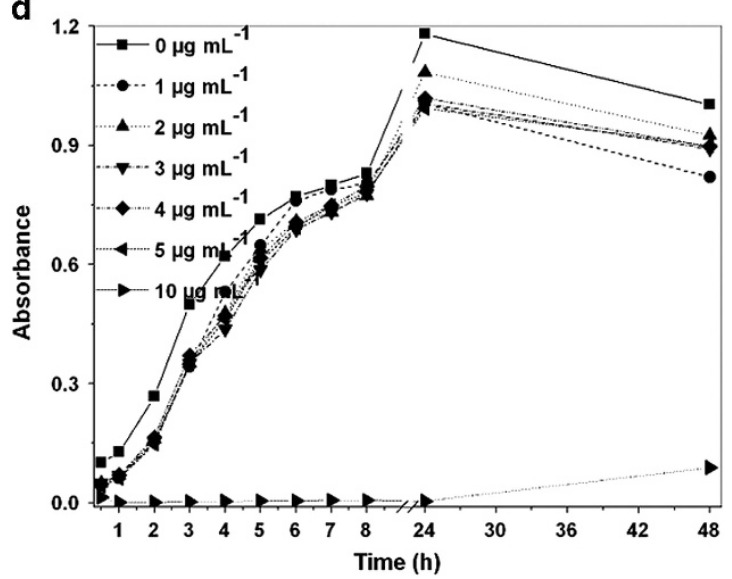

Figure 1 The growth curve of bacteria in nutrient broth supplemented with different concentrations $\left(1-10 \mu g \mathrm{ml}^{-1}\right)$ of silver nanoparticles synthesized with gum ghatti (Ag NP-GT), (a) E. coli 25922, (b) E. coli 35218, (c) P. aeruginosa 27853 and (d) S. aureus 25923.

the lower concentrations up to $4 \mu \mathrm{g} \mathrm{ml}^{-1}$ inhibited the growth for $5 \mathrm{~h}$ only. The growth was resumed with $10 \mu \mathrm{g} \mathrm{ml}^{-1}$ of nanoparticles, after $24 \mathrm{~h}$ (Figure 2a). But with 10-15-nm-sized silver nanoparticles, even a higher concentration of $25 \mu \mathrm{g} \mathrm{ml}^{-1}$ limited the lag phase to about $8 \mathrm{~h}$ only for E. coli $25922 .^{29}$

In the case of the Gram-negative E. coli 35218 strain, the concentrations of 1 and $2 \mu \mathrm{g} \mathrm{ml}^{-1}$ of Ag NP-GT did not cause inhibition. Although the concentrations of $3-10 \mu \mathrm{g} \mathrm{ml}^{-1}$ induced a lag phase for $8 \mathrm{~h}$, beyond $24 \mathrm{~h}$ the cells survived the nanoparticle stress and the growth continued (Figure 1b). In the case of Ag NP-OB, the concentrations beyond $1 \mu \mathrm{g} \mathrm{ml}^{-1}$ induced the lag phase for $8 \mathrm{~h}$ and the growth was resumed after 8 and $24 \mathrm{~h}$ of incubation with 2-3 and $4-5 \mu \mathrm{g} \mathrm{ml}^{-1}$ of nanoparticles, respectively. At a concentration of $10 \mu \mathrm{g} \mathrm{ml}^{-1}$, the growth was completely inhibited (Figure 2b). In an earlier antibacterial characterization study carried out with silver nanoparticles of $16 \mathrm{~nm}$ size against another E. coli strain ATCC 15224, no bacterial growth was noted at $60 \mu \mathrm{g} \mathrm{ml}^{-1}$ concentration. $^{30}$ But such phenomenon of complete inhibition was observed at $10 \mu \mathrm{g} \mathrm{ml}^{-1}$ concentration itself with Ag NP-OB against E. coli 35218. With the same strain of E. coli 35218 and polylysine-capped silver nanoparticles of $7.2 \mathrm{~nm}$ size, a concentration of $50 \mu \mathrm{g} \mathrm{ml}^{-1}$ only extended the lag phase for $5 \mathrm{~h} .{ }^{31}$ For the $P$. aeruginosa 27853 , the lag phase was lengthened by 8 and $24 \mathrm{~h}$ with $3-4$ and $5-10 \mu \mathrm{g} \mathrm{ml}^{-1}$ of Ag NP-GT, respectively. At a concentration of $10 \mu \mathrm{g} \mathrm{ml}^{-1}$, the growth was arrested completely (Figure 1c). With Ag NP-OB, the lag phase was expanded by 8 and $24 \mathrm{~h}$ with 3 and $4-10 \mu \mathrm{g} \mathrm{ml}^{-1}$, respectively, and $10 \mu \mathrm{g} \mathrm{ml}^{-1}$ of nanoparticles totally seized the growth (Figure 2c). Thus, all the Gram-negative strains showed similar trend of growth inhibition (Ag NP-OB $>$ Ag NP-GT) with the nanoparticles tested.

Nevertheless, with Ag NP-GT and Ag NP-OB, a concentration of $10 \mu \mathrm{g} \mathrm{ml}^{-1}$ was able to stop the cell division totally for the Grampositive $S$. aureus 25923 and the concentrations below $10 \mu \mathrm{g} \mathrm{ml}^{-1}$ did not induce lag phase (Figures $1 \mathrm{~d}$ and $2 \mathrm{~d}$ ). The order of inhibition was found to be Ag NP-OB $\geqslant$ Ag NP-GT for S. aureus 25923. With the same strain of $S$. aureus 25923, the concentration of $100 \mu \mathrm{g} \mathrm{ml}^{-1}$ elicited only a partial growth inhibition with silver nanoparticles $10-15 \mathrm{~nm}$ synthesized with glucose and hydrazine. ${ }^{29}$ The bacterial cultures without nanoparticles did not show any inhibition and reached the stationary phase at the end of $48 \mathrm{~h}$. The enhanced growth inhibition activity of the biogenic nanoparticles can be attributed to superior stability of the nanoparticle solutions. ${ }^{29}$ The data on growth curve indicates a faster inhibition in Gram-negative bacteria compared with Gram-positive bacteria. ${ }^{21,29}$ Thus, the inhibition of growth depends on the type of bacterial strain as well as the concentration and particle size of nanoparticles.

\section{Leakage of cytoplasmic contents}

The damage to bacterial cytoplasmic membrane induced by silver nanoparticles was studied in terms of leakage of cytoplasmic contents. ${ }^{19}$ The amount of nucleic acids and proteins released into 
a

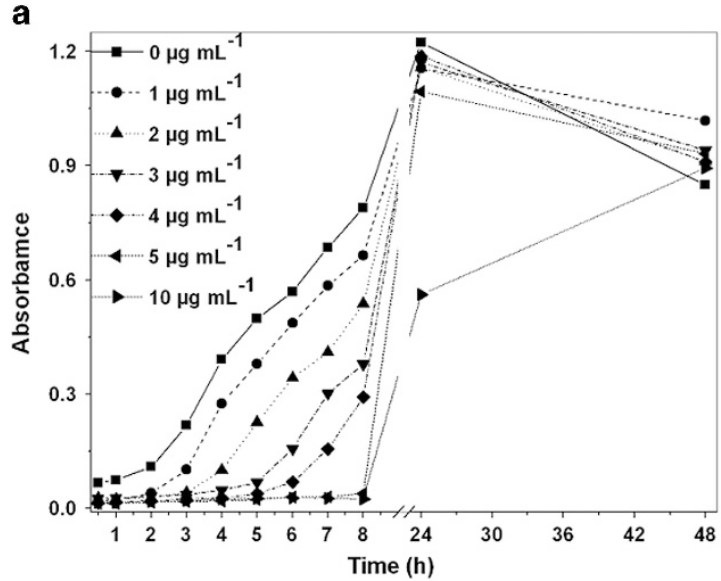

C

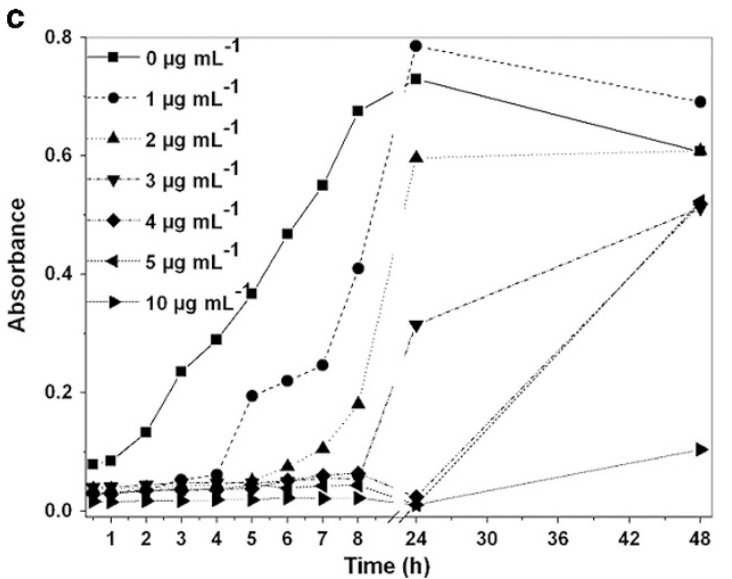

b

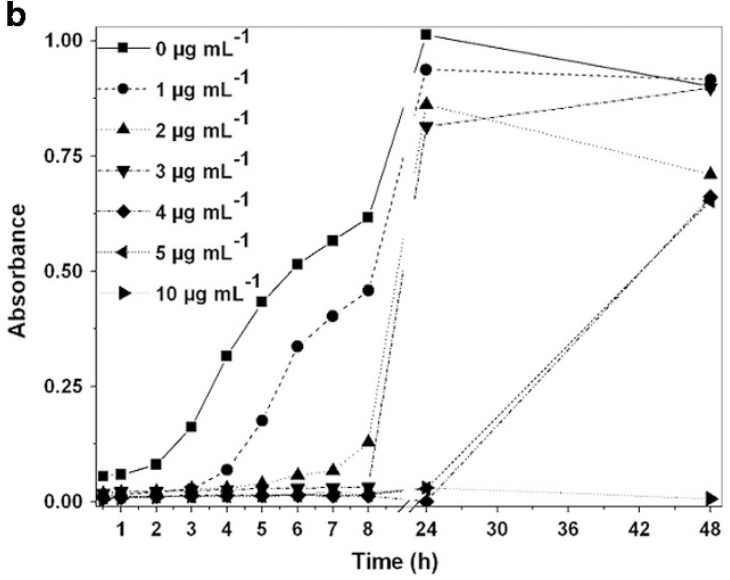

d

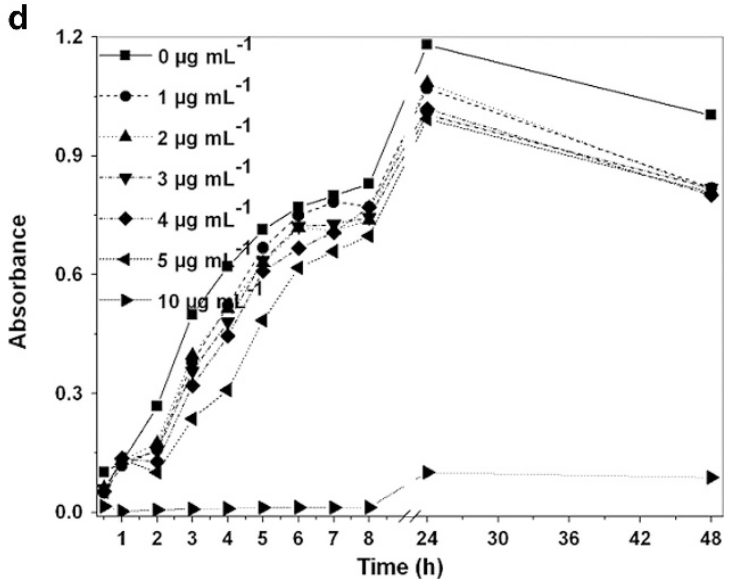

Figure 2 The growth curve of bacteria in nutrient broth supplemented with different concentrations $\left(1-10 \mu g \mathrm{ml}^{-1}\right)$ of silver nanoparticles synthesized with gum olibanum (Ag NP-OB), (a) E. coli 25922, (b) E. coli 35218, (c) P. aeruginosa 27853 and (d) S. aureus 25923.
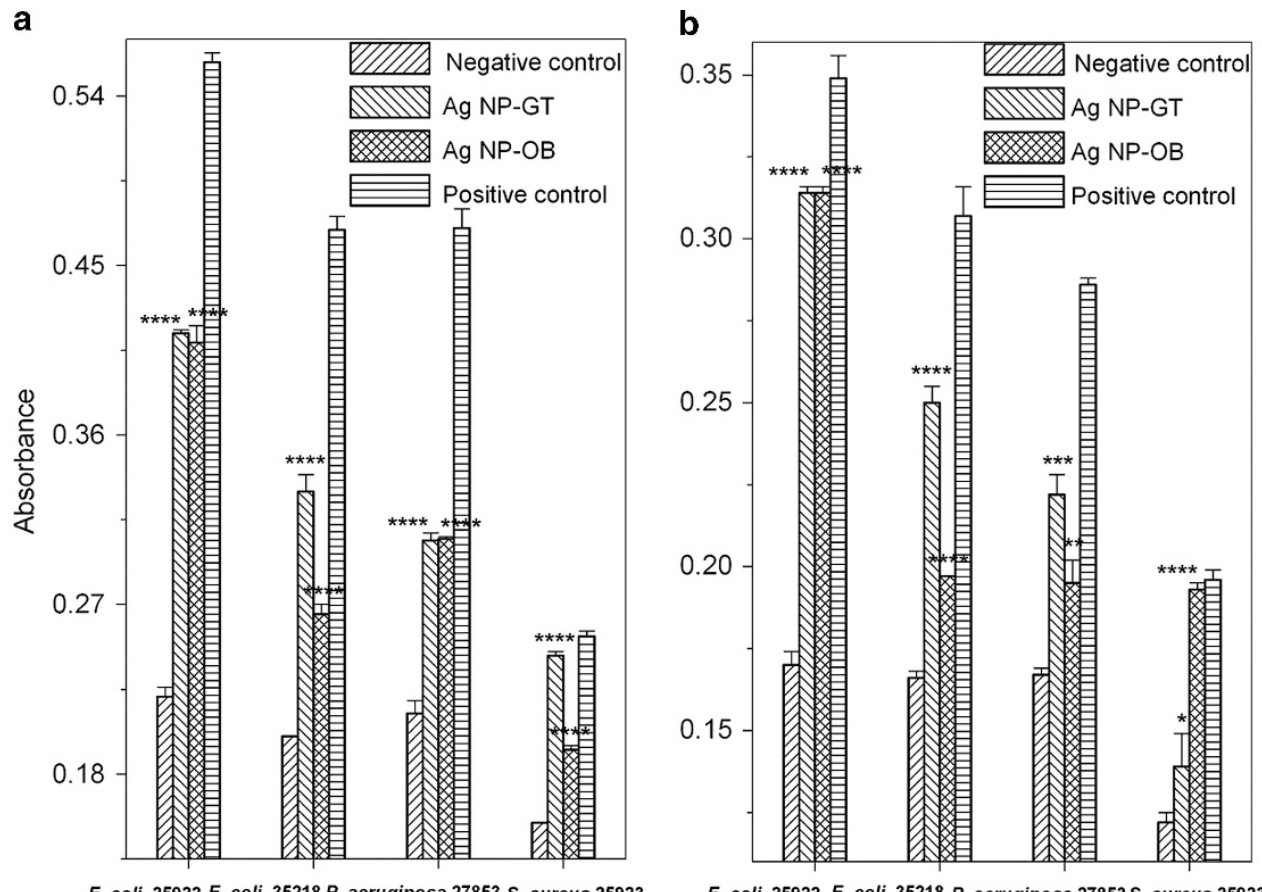

Figure 3 The release of (a) 260-nm and (b) 280-nm absorbing materials from the cell suspensions of bacteria treated with silver nanoparticles (Ag NP)synthesized with gum ghatti (GT) and Ag NP-synthesized with gum olibanum (OB). Values are mean \pm s.d. $(n=3) ;{ }^{*} P<0.05,{ }^{* *} P<0.005,{ }^{* * *} P<0.001$ and $* * * * P<0.0001$ compared with negative control. 
the suspension was determined by measuring the absorbance at 260 and $280 \mathrm{~nm}$. At $5 \mu \mathrm{g} \mathrm{ml}^{-1}$ concentration of nanoparticles, the highest release of nucleic acids and proteins was observed with $E$. coli 25922, followed by E. coli 35218, P. aeruginosa 27853 and S. aureus 25923. The release of nucleic acids were found to be in the order Ag NP-GT > Ag NP-OB for the E. coli 25922, E. coli 35218 and S. aureus 25923; and Ag NP-OB $\geqslant$ Ag NP-GT for $P$. aeruginosa 27853. In the case protein leakage, the order was Ag NP-GT > Ag NP-OB for E. coli 35218 and $P$. aeruginosa 27853; Ag NP-GT $=$ Ag NP-OB for $E$. coli 25922 and Ag NP-OB $>$ Ag NP-GT for S. aureus 25923, respectively (Figure 3). Among the selected strains, the strain S. aureus 25923 was more resistant to nanoparticles when compared with other Gramnegative strains. ${ }^{21}$

\section{Outer membrane damage}

The outer membrane permeabilization activity of biogenic nanoparticles was assessed by measuring the characteristic fluorescence via uptake of hydrophobic NPN. It is mainly due to the destabilizing interaction of nanoparticles with membrane components. ${ }^{22}$ At $3 \mu \mathrm{g} \mathrm{ml}^{-1}$ concentration of nanoparticles, the outer membrane damage was Ag NP-GT $>$ Ag NP-OB for all the Gram-negative bacterial strains (Figure 4). From the data, it is apparent that among the Gram-negative strains, E. coli 35218 was least susceptible to the outer membrane permeabilization by both the nanoparticles. Interestingly, in E. coli 35218 the activity of the both the nanoparticle preparations was more than the positive control hydrogen peroxide.

\section{Effect of antioxidant on the bactericidal activity of silver} nanoparticles

The involvement of ROS in the antibacterial effect of silver nanoparticles was studied using NAC as an antioxidant. In the control petri plates with NAC alone, the bacterial colonies were clearly seen with no growth inhibition. However, in the petri plates supplemented with $5 \mu \mathrm{g} \mathrm{ml}^{-1}$ of Ag NP-GT nanoparticles, no bacterial colonies were observed due to complete inhibition of growth. Whereas in the petri plates supplemented with both NAC and silver nanoparticles the

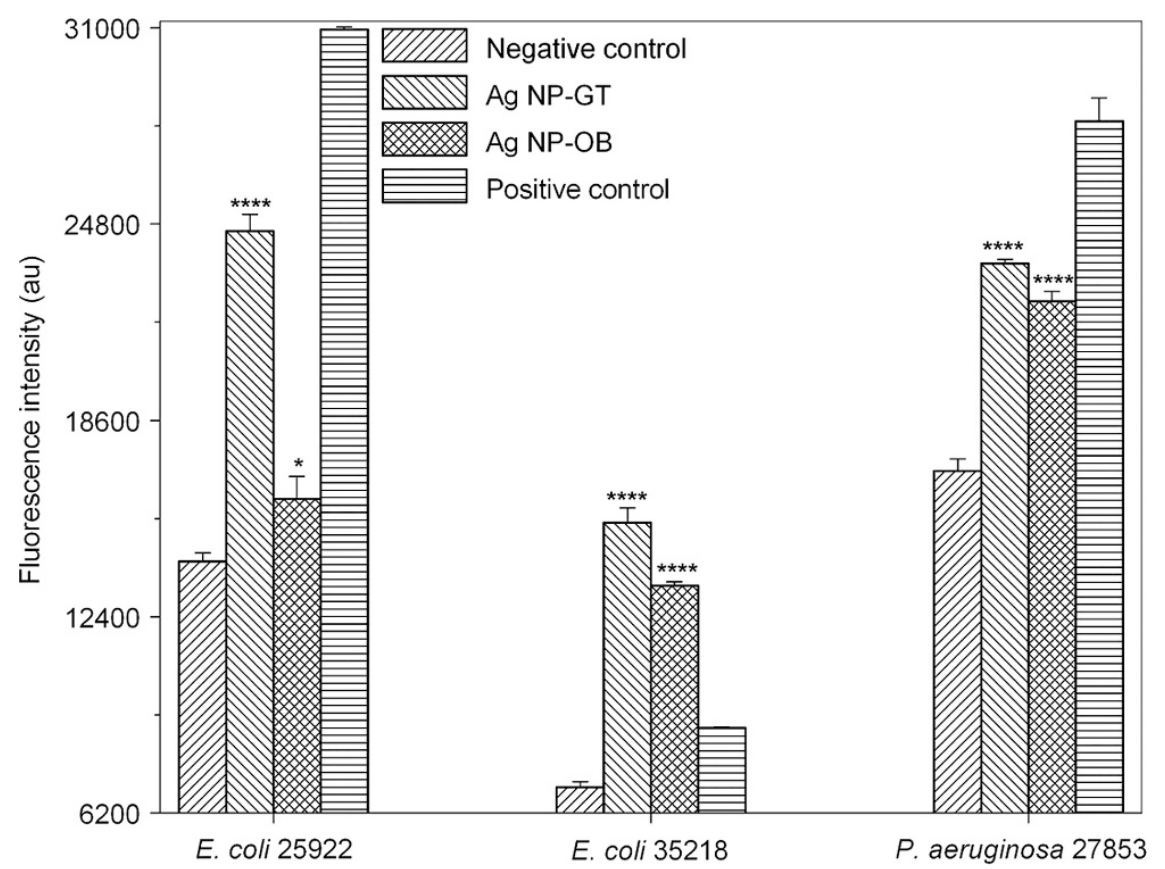

Figure 4 The uptake of $\mathrm{N}$-phenyl naphthylamine (NPN) in bacteria induced by treatment with silver nanoparticles (Ag NP)-synthesized with gum ghatti (GT) and Ag NP-synthesized with gum olibanum (OB). Values are mean \pm s.d. $(n=3) ;{ }^{*} P<0.05$ and ${ }^{* * * *} P<0.0001$ compared with negative control.

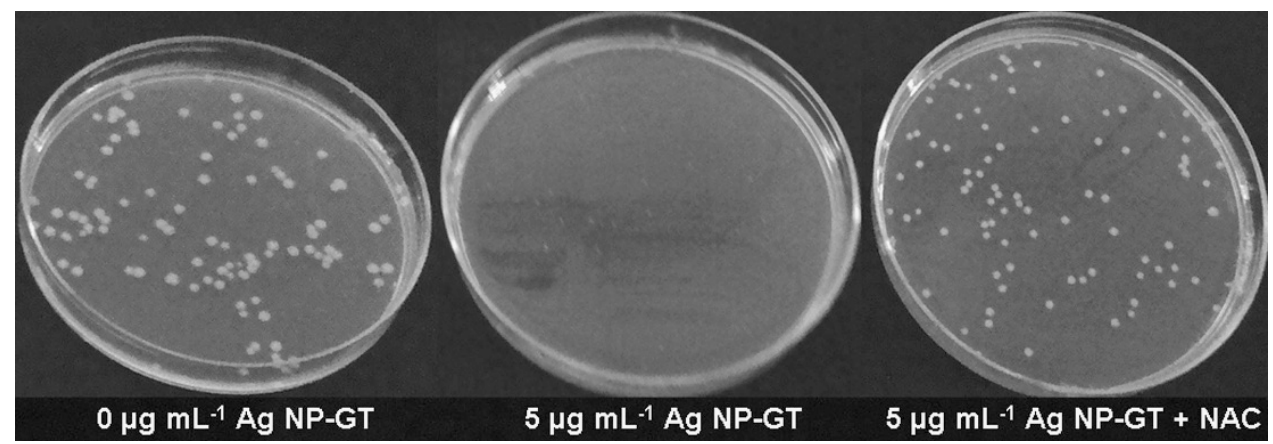

Figure 5 The Petri plates showing the effect of antioxidant $N$-acetylcysteine (NAC) on the bactericidal activity of silver nanoparticles synthesized with gum ghatti (Ag NP-GT) on E. coli 35218. A full color version of this figure is available at The Journal of Antibiotics journal online. 
bacterial colonies were observed (Figure 5). From these photographs, it is evident that ROS are involved in the bactericidal activity of nanoparticles, and NAC acted as a scavenger and protected the E. coli 35218 cells from Ag NP-GT. This observation is in concurrence with earlier studies on antimicrobial effects of silver nanoparticles. ${ }^{12}$
The percentage survival of bacteria in the presence of NAC and silver nanoparticles is depicted in Figure 6. For the Gram-positive S. aureus, NAC was able to protect the bacterial cells almost completely (97\% and 93.4\%) from the toxicity of Ag NP-GT and Ag NP-OB, respectively. A similar trend was observed with other Gram-negative

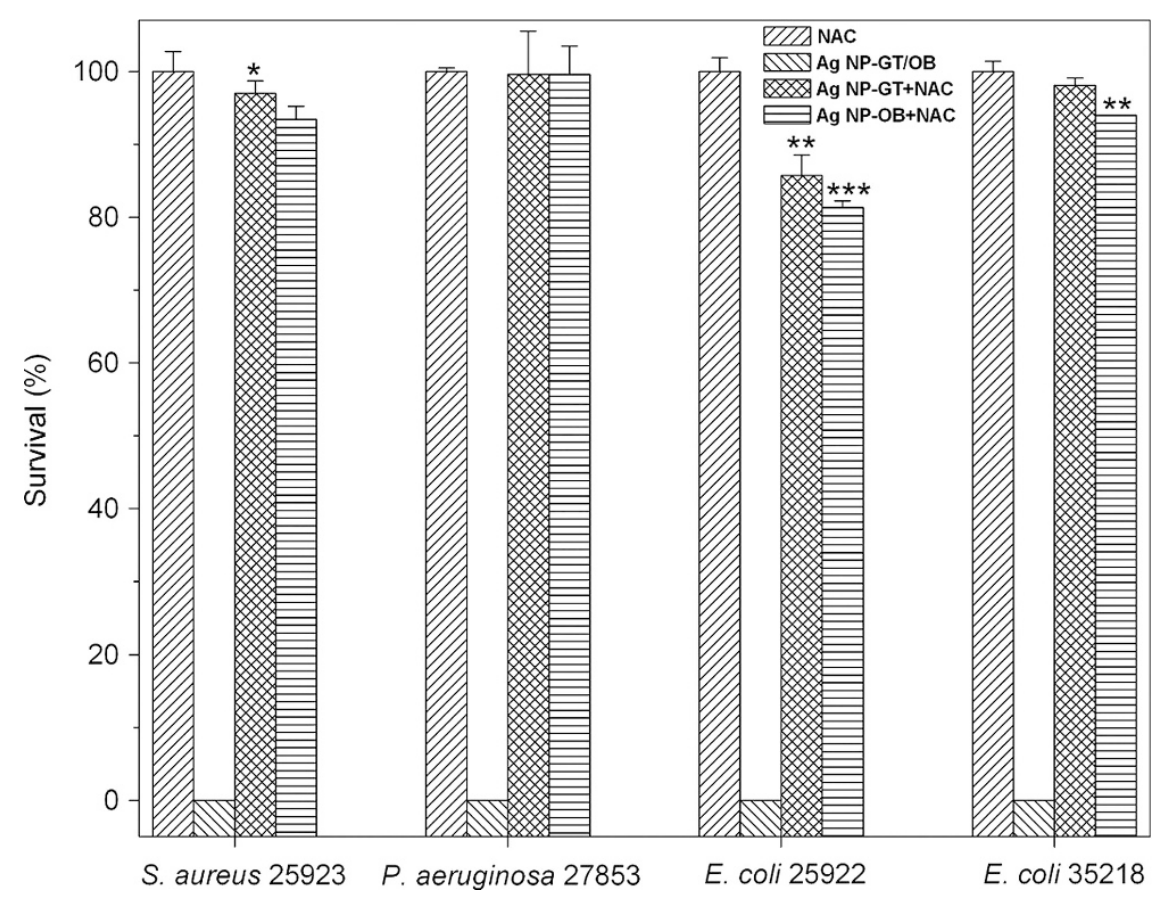

Figure 6 The bar graph showing the percentage of viable cells in the presence of antioxidant $N$-acetylcysteine (NAC) and $5 \mu \mathrm{m} \mathrm{ml}$ of silver nanoparticles (Ag NP)-synthesized with gum ghatti (GT) and Ag NP-synthesized with gum olibanum (OB). Values are mean \pm s.d. $(n=3) ;{ }^{*} P<0.05,{ }^{* *} P<0.005$ and $* * * P<0.001$ compared with control.

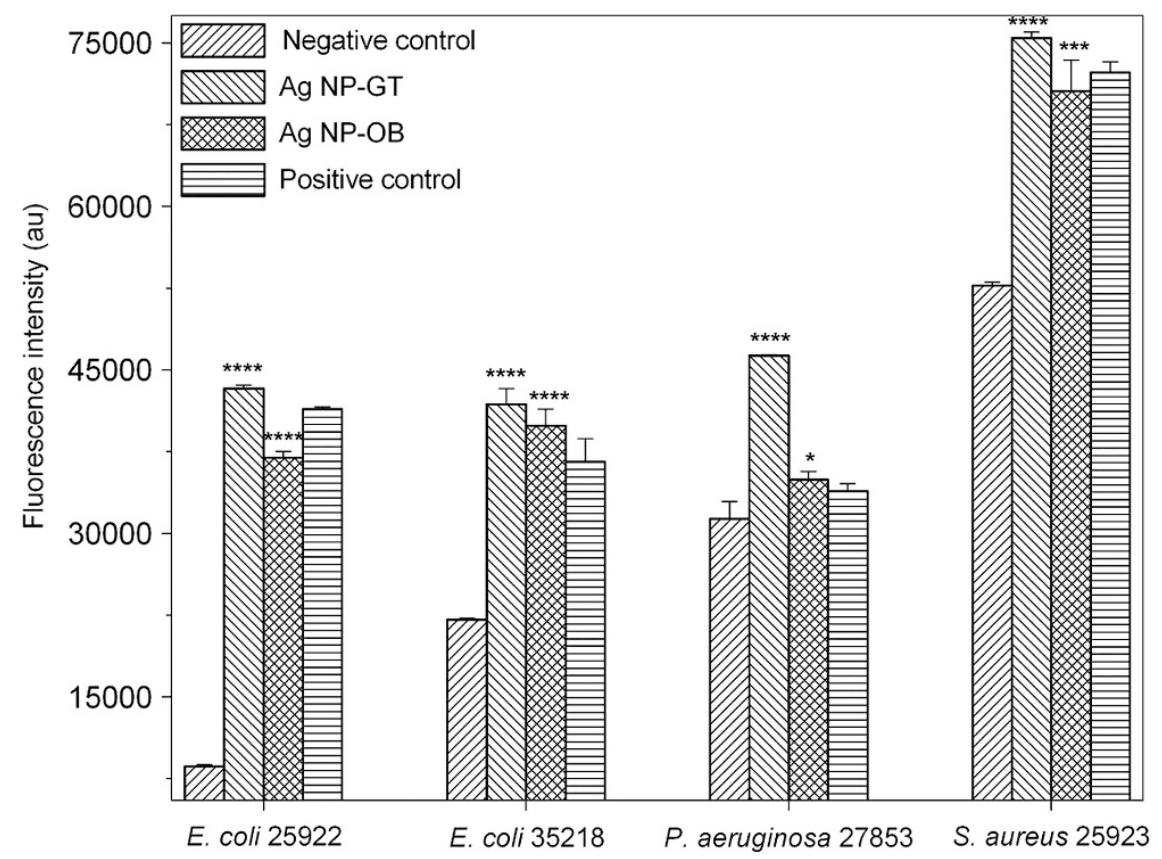

Figure 7 The production of intracellular ROS in the bacterial cell suspensions treated with silver nanoparticles (Ag NP)-synthesized with gum ghatti (GT) and Ag NP-synthesized with gum olibanum (OB). Values are mean \pm s.d. $(n=3) ;{ }^{*} P<0.05$ and ${ }^{* * * *} P<0.0001$ compared with negative control. 
strains P. aeruginosa $27853(99.6 \%)$ and E. coli $35218(98.1 \%$ and $94 \%$ ), respectively. However, NAC was able to protect only $85.7 \%$ and 81.3\% of cells from Ag NP-GT and Ag NP-OB, respectively, for E. coli
25922. Among the selected strains, E. coli 25922 was found to be more sensitive and was unable to recover completely from the bactericidal activity of nanoparticles, even with NAC supplementation.

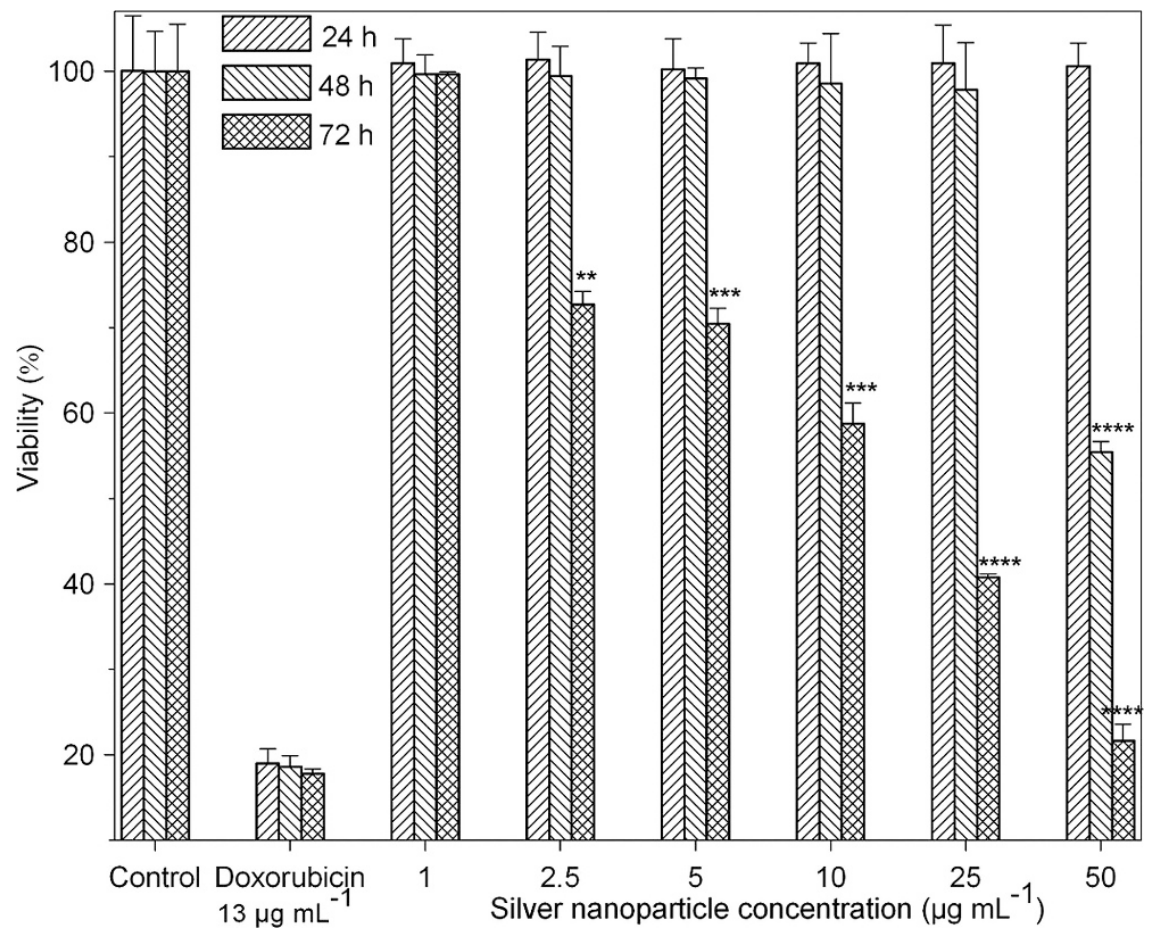

Figure 8 The effect of silver nanoparticles synthesized with gum ghatti (Ag NP-GT) on the cell viability of HeLa cell line at various concentrations. Values are mean \pm s.d. $(n=3) ; * * P<0.005, * * * P<0.001$ and ${ }^{* * * *} P<0.0001$ compared with untreated cells.

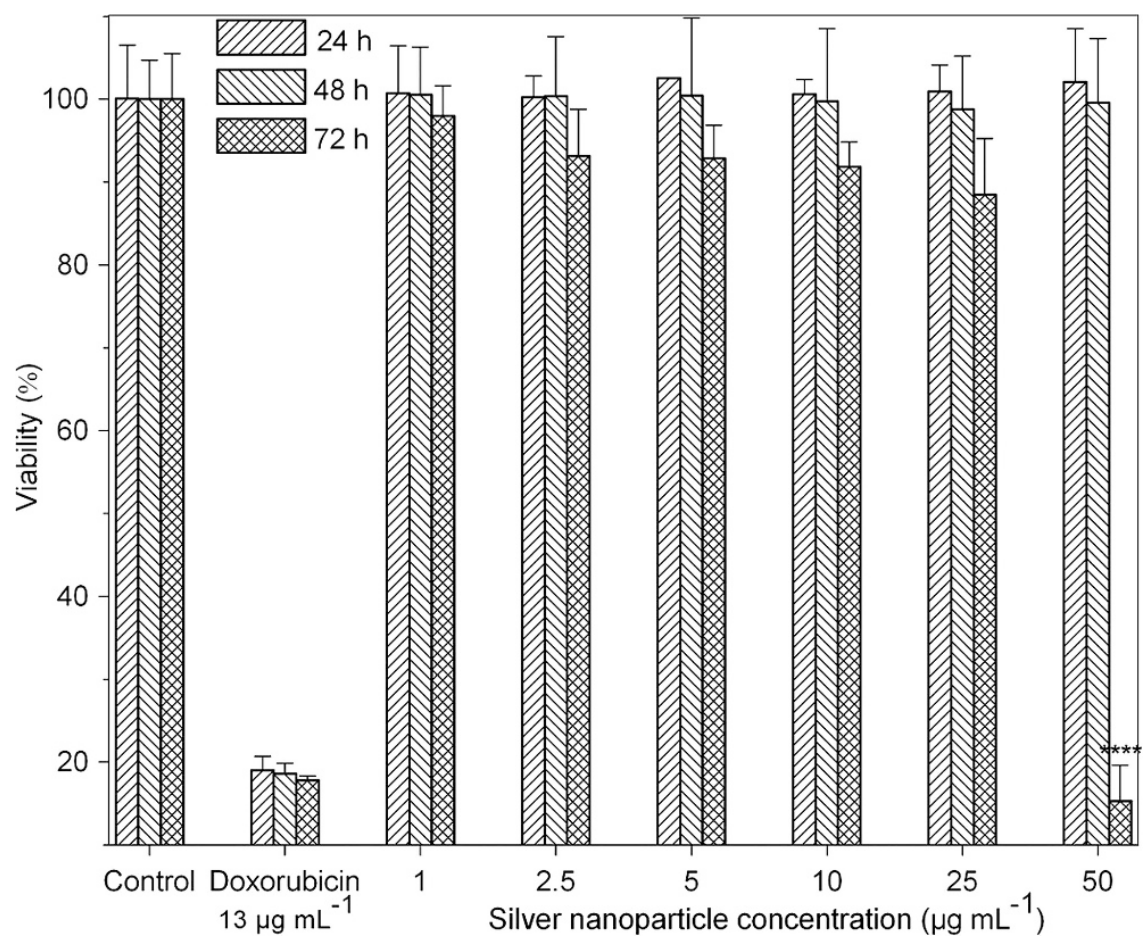

Figure 9 The effect of silver nanoparticles synthesized with gum olibanum (Ag NP-OB) on the cell viability of HeLa cell line at various concentrations. Values are mean \pm s.d. $(n=3) ; * * * * P<0.0001$ compared with untreated cells. 


\section{Detection of intracellular ROS}

The response of bacterial strains toward biogenic nanoparticles is depicted in terms of ROS production, an indicator for cellular oxidative stress. For S. aureus 25923, E. coli 25922 and E. coli 35218 , the generation of ROS is comparable with positive control $30 \mu \mathrm{M} \mathrm{H}_{2} \mathrm{O}_{2}$, at $2 \mu \mathrm{g} \mathrm{ml}^{-1}$ of silver nanoparticles. In the case of P. aeruginosa 27853, the intracellular ROS was more than the positive control (Figure 7). Among the selected strains, the production of intracellular ROS was highest in S. aureus 25923. From the graph, it is evident that the generation of intracellular ROS was found to be Ag NP-GT $>$ Ag NP-OB for all the tested strains.

\section{Cytotoxicity evaluation}

The biocompatibility of the biogenic silver nanoparticles with HeLa cell line was evaluated in terms of cell proliferation. The percentage viability of the cells was plotted against various nanoparticle concentrations at different time intervals. With Ag NP-GT, the nanoparticles were biocompatible only at $1 \mu \mathrm{g} \mathrm{ml}^{-1}$ concentration. From $2.5 \mu \mathrm{g} \mathrm{ml}^{-1}$ onward they were cytotoxic and the viability was reduced to $70.4 \%, 58.7 \%, 40.7 \%$ and $21.6 \%$ at the respective concentrations of $5,10,25$ and $50 \mu \mathrm{g} \mathrm{ml}^{-1}$ at $72 \mathrm{~h}$ (Figure 8 ). Hence,

Table 3 Comparative account of the antibacterial activity of Ag NP. GT and Ag NP-OB

\begin{tabular}{|c|c|c|}
\hline Test parameter & Efficacy & Applicable strains \\
\hline ZOI & Ag NP-GT>Ag NP-OB & All test strains \\
\hline \multicolumn{3}{|l|}{ Antibacterial activity } \\
\hline MIC & $\mathrm{Ag} N \mathrm{~N}-\mathrm{GT}=\mathrm{Ag} \mathrm{NP}-\mathrm{OB}$ & All test strains \\
\hline \multirow[t]{2}{*}{$\mathrm{MBC}$} & $\mathrm{Ag} N \mathrm{~N}-\mathrm{GT}=\mathrm{Ag} \mathrm{NP}-\mathrm{OB}$ & E. coli 25922 \\
\hline & Ag NP-GT>Ag NP-OB & $\begin{array}{l}\text { P. aeruginosa } 27853 \\
\text { E. coli } 35218 \\
\text { S. aureus } 25923\end{array}$ \\
\hline \multirow[t]{2}{*}{ Growth inhibition } & Ag NP-OB $>$ Ag NP-GT & E. coli 25922 \\
\hline & Ag NP-OB $\geqslant$ Ag NP-GT & $\begin{array}{l}\text { E. coli } 35218 \\
\text { P. aeruginosa } 27853 \\
\text { S. aureus } 25923\end{array}$ \\
\hline Antibiofilm activity & $\mathrm{Ag} N \mathrm{~N}-\mathrm{GT}=\mathrm{Ag} \mathrm{NP}-\mathrm{OB}$ & All test strains \\
\hline Leakage of nucleic acids & $\begin{array}{l}\text { Ag NP-GT }>\text { Ag NP-OB } \\
\text { Ag NP-OB } \geqslant \text { Ag NP-GT }\end{array}$ & $\begin{array}{l}\text { E. coli } 25922 \\
\text { E. coli } 35218 \\
\text { S. aureus } 25923 \\
\text { P. aeruginosa } 27853\end{array}$ \\
\hline Leakage of proteins & $\begin{array}{l}\text { Ag NP-GT>Ag NP-OB } \\
\text { Ag NP-GT }=\text { Ag NP-OB } \\
\text { Ag NP-OB }>\text { Ag NP-GT }\end{array}$ & $\begin{array}{l}\text { E. coli } 35218 \\
\text { P. aeruginosa } 27853 \\
\text { E. coli } 25922 \\
\text { S. aureus } 25923\end{array}$ \\
\hline Outer membrane damage & Ag NP-GT > Ag NP-OB & $\begin{array}{l}\text { E. coli } 25922 \\
\text { E. coli } 35218 \\
\text { P. aeruginosa } 27853\end{array}$ \\
\hline ROS and bactericidal activity & Ag NP-OB $\geqslant$ Ag NP-GT & $\begin{array}{l}\text { E. coli } 35218 \\
\text { E. coli } 25922 \\
\text { S. aureus } 25923 \\
\text { P. aeruginosa } 27853\end{array}$ \\
\hline Intracellular ROS production & Ag NP-GT>Ag NP-OB & All test strains \\
\hline \multicolumn{3}{|l|}{ Biocompatibility } \\
\hline Cytotoxicity & Ag NP-GT>Ag NP-OB & HeLa cell line \\
\hline
\end{tabular}

the Ag NP-GT elicited a dose-dependent effect on the proliferation of HeLa cell line in MTT assay. ${ }^{32,33}$ Whereas with Ag NP-OB, the cytotoxic effect was observed only at $50 \mu \mathrm{g} \mathrm{ml}^{-1}(15.2 \%)$ and the concentrations up to $25 \mu \mathrm{g} \mathrm{ml}^{-1}$ were not cytotoxic (Figure 9). The biogenic nanoparticles of $5.7 \mathrm{~nm}$ size (Ag NP-GT) were cytotoxic beyond $2.5 \mu \mathrm{g} \mathrm{ml}^{-1}$, whereas with $7.5 \mathrm{~nm}$ size (Ag NP-OB) they were biocompatible up to a concentration of $25 \mu \mathrm{g} \mathrm{ml}-1$. With latexcapped silver nanoparticles of $10 \mathrm{~nm}$ size, the antiproliferation effect was noted at $100 \mu \mathrm{g} \mathrm{ml}^{-1} .^{32}$ Thus, the results indicate a dependency of cytotoxic concentration on particle size. These results are in tune with earlier cytotoxic studies carried out with chitosan nanoparticles of different sizes. Also, the enhanced cytotoxicity of the Ag NP-GT can be correlated to its higher zeta potential values in comparison with $\mathrm{Ag} \mathrm{NP}-\mathrm{OB} .{ }^{33}$ On the basis of these observations, it can be concluded that the synthesized biogenic nanoparticles have dual potential applications. ${ }^{16}$ The nanoparticles with superior toxicity (Ag NP-GT) may be employed as cytotoxic bactericidal agents, whereas the benign ones (Ag NP-OB) as biocompatible bactericidal agents.

The antibacterial activity of both the biogenic silver nanoparticles was compared in terms of ZOI, MIC, MBC, inhibition of growth kinetics, antibiofilm activity, membrane damage, ROS production and cytotoxicity (Table 3 ). It was observed that with most of the used parameters, the efficacy of Ag NP-GT was more than Ag NP-OB. The enhanced antibacterial and cytotoxicity activities of Ag NP-GT could be attributed to the smaller size, monodispersity and zeta potential of the nanoparticles (Table 4). The gum ghatti is an arabinogalactan type of gum and is composed of sugars such as arabinose, galactose, mannose, xylose, rhamnose and glucuronic acid. It has a MW of $8.9 \times 10^{7} \mathrm{~g} \mathrm{~mol}^{-1}$, protein rich and the protein content was reported to be in the range of $2.8-3.7 \% .^{9}$ The gum olibanum is categorized under glucuronoarabinogalactan type and is composed of arabinose, galactose, xylose and glucuronic acid. It has a MW of $5.1-5.6 \times 10^{5} \mathrm{~g} \mathrm{~mol}^{-1}$ and the protein content was reported to be $3.4 \% .{ }^{10}$ Although both the nanoparticles are protein capped, they differ in protein content and composition of the gum, which leads to a difference in the surface functionalization of nanoparticles and zeta potential values.

Table 4 Comparative account of the physical properties of Ag NP-GT and $\mathrm{Ag}$ NP-OB

\begin{tabular}{|c|c|c|}
\hline Parameter & $A g N P-G T^{9}$ & $A g N P-O B^{10}$ \\
\hline Gum used & Gum ghatti & Gum olibanum \\
\hline Type of gum & Arabinogalactan & Glucuronoarabinogalactan \\
\hline $\begin{array}{l}\text { Gum } \\
\text { composition }\end{array}$ & $\begin{array}{l}\text { Arabinose, galactose, mannose, } \\
\text { xylose, rhamnose and glucuronic acid }\end{array}$ & $\begin{array}{l}\text { Arabinose, galactose, } \\
\text { xylose and glucuronic acid }\end{array}$ \\
\hline $\begin{array}{l}\text { MW of gum } \\
\left(\mathrm{g} \mathrm{mol}^{-1}\right)\end{array}$ & $8.9 \times 10^{7}$ & $5.1-5.6 \times 10^{5}$ \\
\hline $\begin{array}{l}\text { Protein content } \\
\text { in gum (\%) }\end{array}$ & $2.8-3.7$ & 3.4 \\
\hline $\begin{array}{l}\text { Particle range } \\
(\mathrm{nm})\end{array}$ & $4.8-6.2$ & $1.9-14.7$ \\
\hline $\begin{array}{l}\text { Average particle } \\
\text { size }(\mathrm{nm})\end{array}$ & $5.7 \pm 0.2$ & $7.5 \pm 3.8$ \\
\hline $\begin{array}{l}\text { Monodispersed } \\
\text { particles (\%) }\end{array}$ & 70 & 50 \\
\hline $\begin{array}{l}\text { Zeta potential } \\
(\mathrm{mV})\end{array}$ & $-22.4 \pm 8.7$ & $-14.9 \pm 6.6$ \\
\hline
\end{tabular}




\section{CONCLUSIONS}

The highly stable biogenic silver nanoparticles had significant antibacterial action on planktonic and biofilm modes of bacterial growth against Gram-negative and Gram-positive bacteria. Also, the ZOI, MIC and MBC values observed are higher than the reported values. Thus, the biogenic antibacterial silver nanoparticles generated with gums have an advantage over the other chemogenic silver nanoparticles. Among the selected strains, Gram-positive S. aureus 25923 was more resistant to membrane damage and growth curve inhibition when compared with other Gram-negative strains tested. The biocompatibility of the silver nanoparticles with HeLa indicated the dependency of cytotoxic concentration on particle size and zeta potential. It was found that Ag NP-GT was a more potent bactericidal and cytotoxic agent than Ag NP-OB. The enhanced antibacterial activity of Ag NP-GT enables it to be an effective bactericidal agent, whereas the non-cytotoxic nature of Ag NP-OB makes it a candidate of choice for biocompatible bactericidal activity. Further studies need to be carried out to find out the actual surface functional molecules that are responsible for differential activity of these biogenic silver nanoparticles capped with proteins from natural plant gums.

\section{ACKNOWLEDGEMENTS}

We thank Dr J. Arunachalam, Former Head, NCCCM for his constant support and encouragement.

1 Raveendran, P., Fu, J. \& Wallen, S. L. Completely ‘green' synthesis and stabilization of metal nanoparticles. J. Am. Chem. Soc. 125, 13940-13941 (2003).

2 Vigneshwaran, N., Nachane, R. P., Balasubramanya, R. H. \& Varadarajan, P. V. A novel one-pot 'green' synthesis of stable silver nanoparticles using soluble starch. Carbohydr. Res. 341, 2012-2018 (2006).

3 Gericke, M. \& Pinches, A. Microbial production of gold nanoparticles. Gold Bull. 39, 22-28 (2006).

4 Kumar, C. G. \& Mamidyala, S. K. Extracellular synthesis of silver nanoparticles using culture supernatant of Pseudomonas aeruginosa. Colloid. Surf. B 84, 462-466 (2011).

5 Vigneshwaran, N. et al. Biological synthesis of silver nanoparticles using the fungus Aspergillus flavus. Mater. Lett. 61, 1413-1418 (2007)

6 Govindaraju, K., Kiruthiga, V., Kumar, V. G. \& Singaravelu, G. Extracellular synthesis of silver nanoparticles by a marine alga, Sargassum wightii Grevilli and their antibacterial effects. J. Nanosci. Nanotechnol. 9, 5497-5501 (2009).

7 Shankar, S. S., Rai, A., Ahmad, A. \& Sastry, M. Rapid synthesis of Au, Ag, and bimetallic Au core-Ag shell nanoparticles using neem (Azadirachta indica) leaf broth. J. Colloid Interf. Sci. 275, 496-502 (2004).

8 Thakkar, K. N., Mhatre, S. S. \& Parikh, R. Y. Biological synthesis of metallic nanoparticles. Nanomed. Nanotechnol. Biol. Med. 6, 257-262 (2010).

9 Kora, A. J., Sashidhar Rao, B. \& Jayaraman, A. Size-controlled green synthesis of silver nanoparticles mediated by gum ghatti (Anogeissus latifolia) and its biological activity. Org. Med. Chem. Lett. 2, 1-10 (2012).
10 Kora, A. J., Sashidhar, R. B. \& Arunachalam, J. Aqueous extract of gum olibanum (Boswellia serrata): a reductant and stabilizer for the biosynthesis of antibacterial silver nanoparticles. Process Biochem. 47, 1516-1520 (2012).

11 Cho, K.-H., Park, J.-E., Osaka, T. \& Park, S.-G. The study of antimicrobial activity and preservative effects of nanosilver ingredient. Electrochim. Acta 51, 956-960 (2005).

$12 \mathrm{Kim}$, J. S. et al. Antimicrobial effects of silver nanoparticles. Nanomed. Nanotechnol. Biol. Med. 3, 95-101 (2007).

13 Panacek, A. et al. Silver colloid nanoparticles: synthesis, characterization, and their antibacterial activity. J. Phys. Chem. B 110, 16248-16253 (2006).

14 Sharma, V. K., Yngard, R. A. \& Lin, Y. Silver nanoparticles: green synthesis and their antimicrobial activities. Adv. Colloid Interf. Sci. 145, 83-96 (2009).

15 Sondi, I. \& Salopek-Sondi, B. Silver nanoparticles as antimicrobial agent: a case study on E. coli as a model for Gram-negative bacteria. J. Colloid Interf. Sci. 275, 177-182 (2004).

16 Suresh, A. K. et al. Silver nanocrystallites: Biofabrication using Shewanella oneidensis, and an evaluation of their comparative toxicity on Gram-negative and Gram-positive bacteria. Environ. Sci. Technol. 44, 5210-5215 (2010).

17 Martınez-Castanon, G. A., Nino-Martınez, N., Martınez-Gutierrez, F., Martınez-Mendoza, J. R. \& Ruiz, F. Synthesis and antibacterial activity of silver nanoparticles with different sizes. J. Nanopart. Res. 10, 1343-1348 (2008).

18 Uhlich, G. A., Cooke, P. H., \& Solomon, E. B. Analyses of the red-dry-rough phenotype of an Escherichia coli 0157:H7 strain and its role in biofilm formation and resistance to antibacterial agents. Appl. Environ. Microbiol. 72, 2564-2572 (2006).

19 Chen, C. Z. \& Cooper, S. L. Interactions between dendrimer biocides and bacterial membranes. Biomaterials 23, 3359-3368 (2002).

20 Liu, H., Du, Y., Wang, X. \& Sun, L. Chitosan kills bacteria through cell membrane damage. Inter. J. Food Microbiol. 95, 147-155 (2004).

21 Tiwari, D. K., Behari, J. \& Sen, P. Time and dose-dependent antimicrobial potential of Ag nanoparticles synthesized by top-down approach. Curr. Sci. 95, 647-655 (2008).

22 Helander, I. M. \& Mattila-Sandholm, T. Fluorometric assessment of Gram-negative bacterial permeabilization. J. Appl. Microbiol. 88, 213-219 (2000).

23 Ahamed, M., Majeed Khan, M. A., Siddiqui, M. K. J., AlSalhi, M. S. \& Alrokayan, S. A. Green synthesis, characterization and evaluation of biocompatibility of silver nanoparticles. Physica E 43, 1266-1271 (2011).

24 Du, W.-L., Niu, S.-S., Xu, Y.-L., Xu, Z.-R. \& Fan, C.-L. Antibacterial activity of chitosan tripolyphosphate nanoparticles loaded with various metal ions. Carbohydr. Polym. 75, 385-389 (2009).

25 Ruparelia, J. P., Chatterjee, A. K., Duttagupta, S. P. \& Mukherii, S. Strain specificity in antimicrobial activity of silver and copper nanoparticles. Acta Biomater. 4, 707-716 (2008).

26 Jaidev, L. R. \& Narasimha, G. Fungal mediated biosynthesis of silver nanoparticles, characterization and antimicrobial activity. Colloid. Surf. B 81, 430-433 (2010).

27 Kora, A. J., Manjusha, R. \& Arunachalam, J. Superior bactericidal activity of SDS capped silver nanoparticles: Synthesis and characterization. Mater. Sci. Eng. C 29, 2104-2109 (2009).

28 Mohanty, S. et al. An investigation on the antibacterial, cytotoxic, and antibiofilm efficacy of starch-stabilized silver nanoparticles. Nanomed. Nanotechnol. Biol. Med. 8, 916-924 (2012)

29 Siddhartha, S. et al. Characterization of enhanced antibacterial effects of novel silver nanoparticles. Nanotechnology 18, 225103-225111 (2007).

30 Raffi, M. et al. Antibacterial characterization of silver nanoparticles against $E$. Coli ATCC-15224. J. Mater. Sci. Technol. 24, 192-196 (2008)

31 Dror-Ehre, A., Mamane, H., Belenkova, T., Markovich, G. \& Adin, A. Silver nanoparticle-E. coli colloidal interaction in water and effect on E. coli survival. J. Colloid Interf. Sci. 339, 521-526 (2009).

32 Valodkar, M. N., Jadeja, R. C., Thounaojam, M. V., Devkar, R. \& Thakore, S. In vitro toxicity study of plant latex capped silver nanoparticles in human lung carcinoma cells. Mater. Sci. Eng. C 31, 1723-1728 (2011).

33 Qi, L., Xu, Z., Jiang, X., Li, Y. \& Wang, M. Cytotoxic activities of chitosan nanoparticles and copper-loaded nanoparticles. Bioorg. Med. Chem. Lett. 15, 1397-1399 (2005).

Supplementary Information accompanies the paper on The Journal of Antibiotics website (http://www.nature.com/ja) 